\title{
Evasive Youth, Oblique Politics
}

\author{
Elina Oinas, Henri Onodera and Leena Suurpää
}

\section{Introduction}

Amina 'returns' to her childhood hometown in Somaliland in high hopes of making a difference and contributing to the reconstruction of her home country with her British education and resources, but she feels neither welcome nor influential. She does not know if her efforts matter, and starts to get disillusioned. If she cannot know, can a researcher know? How does a researcher define 'political', 'influence', or 'making a difference' anywhere, let alone on Amina's street corner where she has her small business selling imported fashion products, and her new ideas of what femininity could mean? Is it even meaningful to hold on to the concept of politics when analysing Amina's vague sense of social change? Similar concerns about how to achieve a sense of belonging, recognition and engagement are raised by a young man we call John, in Kenya, wondering if he will ever have a fair chance at national politics, given his marginalized background. Meanwhile, Zimbabwean Zizi knows that as a youth league agitator he and his group's violence most certainly has had an impact in the neighbourhood they visited - or terrorized, some would say - but he knows he had little choice.

Alongside the hesitations of Amina, John and Zizi, researchers in youth and politics in Africa encounter stories of life-altering moments of companionship and victory told by young activists. Similar experiences of shared passion and inspiration appear in this volume, recounted, for example, by Thembi in Johannesburg and Muhammad in Cairo. The energy and determination of students who struggle against the institutionalized racism and oppression of black students and workers in today's South Africa, echo in other accounts in quite different circumstances including the leisure spaces near Tahrir Square in downtown Cairo.

Narratives such as these, and the voices of other young people filling the pages below, paint unique pictures of what they hoped for and what then ensued in their lives in different parts of the continent. Regardless of the meaningful doubts and reflexivity among us researchers, there are a surprising number of similarities and overlaps in the analytical discussions in the different chapters of this book. They collectively offer the reader a journey of comparing, 
contrasting and cross-valorizing the agency of contemporary young people in attaining recognition and change in Africa. Despite the ambivalences in the face of the task's magnitude, we as editors have had a growing sense of purposefulness in compiling qualitative case studies of young people's accounts of politics and what matters to them in different parts of Africa, covering moments of excitement and purpose, but also of despair, anger and disillusionment.

All the key terms we use in this book - youth, Africa, politics - are highly contested and should be so. In the course of the different chapters we do not search for uniform meanings but, rather, valorize the key aspects of what young people's engagements are about in contemporary Africa, and how they describe their attempts to carve out spaces of change and autonomy. The empirical realities and the perspectives of youth, as well as the interpretations of the researchers, are discussed against academic literature from a variety of disciplines, often derived from settings that are inherently different from the empirical research sites - the typical mismatch between Northern theory and Southern data applies here too. There is also, however, a need to move beyond exceptionalism and particularizing descriptions of 'Africa' and critically examine how concepts travel and how similar questions may be relevant in diverse settings in the globalizing world (Laine et al. 2015).

\section{'Youth' as an Allusive Yet Meaningful Category}

'African youth' emerged as a powerful category and gained currency in academic and policy-related research at the turn of the millennium (e.g., Christiansen, Utas and Vigh 2006). The growing interest is linked to the sheer numbers of young people in Africa - the youngest continent in the world, with $70 \%$ of its population under 30 years of age - as one of the key global challenges to be managed with an array of development, immigration and social policies (Kelly and Kamp 2015, 7). While Africans currently only comprise $16 \%$ of the world's inhabitants, the continent has the most rapidly growing population (United Nations 2015, 7), and by 2050, more than half of global growth is expected to take place there; currently, the ten countries with the highest fertility rates in the world are in Africa (ibid., 9). The demographic concern is often tied to the urge to governmentality which is traditional in population research.

The growing interest can also be explained by the mounting wave of rebellions, unrest, conflicts and even revolutions on the continent, not least since the popular uprisings in Northern Africa, the so-called 'Arab Spring', in 2011, as well as the increasing migrations of African youth towards the global North. Here, the analysts have focused on the alarming prospects of stifling 
generational and geographical divides and growing, hypervisible inequalities. Both contribute to the creation of affective and interpersonal experiences of marginalization and relative deprivation among young people in terms of their economic, social, and political standing and their life chances in the future, potentially leading to unrest and dissension among them (cf. Resnick and Thurlow 2015; Feixa, Leccardi and Nilan 2016). The concept of gerontocracy - or rule by the elderly - features in most analyses of African politics, pointing to the ways in which young people are systematically denied access to political power or economical resources by older generations.

The notion of the political is, however, unusually challenging to define when attempting to reach a better understanding of youthful engagements in the public life and societies of the vast continent. In the case of Africa, it is pertinent to go beyond discussing mere political participation in existing formal structures, such as the state and the government, as in classic political science - although this caution is relevant everywhere nowadays. In African post-colonial contexts, discussing politics is also hard due to the negative connotations the word 'political' carries in its everyday usage. As with other projects on youth and politics, our point of departure in studying young people's political engagements is, therefore, to be attentive to any "will to enact social change" (Allaste and Cairns 2016, 3). To widen the scope of what can be deemed relevant, the concept of 'participation' is here replaced by the more oblique 'engagement', signalling all kinds of involvements in enacting change that materialize and are felt in everyday life (cf. della Porta and Mattoni 2014).

Networks and mechanisms of power produce subject positions, discourses and ideas on what is considered normal and possible, and moments when these assumptions of power are challenged can be considered political. Deborah Posel makes an interesting and useful distinction between the politics of sexuality and the politicization of sexuality, suggesting that

sexuality is always political, as the site of multiple strategies of regulation and discipline and their uneven effects; but sexuality is only intermittently politicized, in the sense of becoming the site of heated public argument, mobilization and conflict. Thus, if the former is a systemic feature of any modern social order, the latter is the product of historical conjunctures.

POSEL 2005, 127

The political engagements studied in this book are not limited to a study of willful subjects making calculated choices, especially not only in the predetermined arenas of formal democratic apparatuses; rather, using Posel's 
formulation, we discuss specific "historical conjunctures" that are interrupted and acted upon by young people in their everyday lives. At times these refer to spectacular events, such as protests and riots, and at other times to ideological expressions and rhetoric. Simultaneously, however, less visible or articulated forms of discontent and agency are equally relevant for us.

The statistical analysis by Danielle Resnick (2015, 48-49) shows that while there has indeed been a substantial increase in riot and protest activities since 2008 in Africa, the share of specifically youth protests has not grown, and remains low. Youth is in this context defined as the age cohort ${ }_{15}^{-35}$, following the African Union definition that considers the delay in transition into adulthood typical for African societies (Resnick 2015, 51). Statistical evidence is, however, a contested issue, especially regarding political unrest in undemocratic circumstances. Furthermore, even if the reliability of statistics goes unchallenged, qualitative researchers observe that there is a widespread sense of change and protest in the air, and such simmering sentiments and temporary successes potentially fuel each other.

With growing global connectedness through media, migration, technology and both popular and alternative global cultural circuits, the ambivalence of the 'youth' category and what it entails does not solely concern Africa (Suurpää et al. 2015). Mainstream development agencies, such as international financial institutions and national decision makers, operate with clear policy definitions of youth, namely, those belonging to distinct age cohorts (such as 15-29/35 years of age). While such definitions are important for policy purposes, it is obvious that they place insufficient emphasis on the cultural attributes, social meanings and expressions of what being young may contain beyond the age limitations (Clark-Kazak 2009).

The authors in this book represent different fields of the social sciences, including anthropology, sociology and political science, as well as youth research, development research and gender studies. We have not considered it necessary to operationalize a shared understanding of 'youth'; rather, it is viewed here as a context-sensitive category that reflects social, economic, political, moral and emotional predicaments and embodied processes. In other words, being young is seen as a personal, collective and intrinsically cultural experience that is further structured by gender, social class, ethnicity, religion and other social distinctions, as well as the material resources available at a given time. Indeed, we take intersecting positions and identities seriously, giving equal, if not greater, importance to those that were expressed by the young people themselves: such as student, activist, NGO-professional, musician, believer, but also silenced, marginalized, violated, whether in the villages in Kenya and Zimbabwe, Egyptian metropoles, or Niger's university campuses. 
While it is contended that the category of youth is ambivalent and fluid, we acknowledge that it encompasses often normative aspirations, positioning young people as a destabilizing force to be met with and managed, or an illusionary hope for the future. Joschka Philipps (2014) recently summarized the discursive landscape that deals with youth in Africa as prone to paradoxical narratives. Philipps proposes that this feature is documented in the uniform naming practice of publications, like Heroes or Villains (Seekings 1993), Hooligans or Heroes (Perullo 2005), Vanguard or Vandals (Abbink and van Kessel 2005), Makers or Breakers (Honwana and de Boeck 2005), 'Promise or Peril' (Muhula 2007), Troublemakers or Peacemakers (McEvoy-Levy 2006; see Philipps 2014, 1362; Resnick and Thurlow 2015, 1). Philipps suggests that the size and variation within the category - or non-category due to its largeness enable the generalizing level of analysis.

The book titles withstanding, the actual qualitative analysis of youth lives in Africa is seldom oversimplifying, we would argue. The legacy of accountability and commitment in relation to young people themselves works against simplistic descriptions. Research participants do not often account for the richness of their lives in clear-cut terms. Such an accountability means that we envision Thembi and John as well as the Northern scholars and policy makers as our readers. This leads to an aspiration to maintain awe in the face of the complexity of social life, to study without explaining it all, and to respect the evasive and unexplainable in life as an epistemic stance from which to work.

Both Pumla Dineo Gqola (2015) and Kopano Ratele (2016) underline the contradiction when studying young men in South Africa: one must read black men's lives against a history of colonialism and oppression yet not reduce them merely to pawns of history. Further, when researching a violent present the racist frames of interpretation that dominate the way African men are viewed must be interrogated and deconstructed. This double task to historicize and deconstruct is a necessary analytical lens that recalls the importance of situating and contextualizing young people's own versions of their lives, while sometimes moving beyond their own views. It is possible to take the histories of the present seriously, including the often unarticulated but heavily present frame of colonial representations of dangerous youth, even when acknowledging the legacy and ethos of the youth research tradition that young people's perspectives on what matters are valid and important per se. An effort to engage with young people's struggles with neither a sentimental nor overly factualizing tone has been a key ethos in the making of this book.

Anthropologists Diane Singerman (2007) and Alcinda Honwana (2012, 2014) have inspired us with explorations in 'waithood', a prolonged period of suspension between childhood and adulthood that has become a common 
predicament whereby young people are increasingly barred from transitioning to adulthood in their material and cultural contexts. We also agree that it is important not to generalize the predicament but, rather, to examine the everyday experiences of those living in such conditions empirically. Young people improvise solutions not only to cope but also to promote a sense of self that emerges beyond the dominant economic and patrimonial frameworks that indeed hamper their life chances. Institutionalized vulnerability and limited opportunities notwithstanding, as Honwana also suggests, the concept of waithood should not, however, assign overtly passive roles to an entire generation but also indicate opportunities of experimentation, innovation and leisure.

It has been our goal to pay close attention to the setting and the actors who materialize through the processes of becoming, which are always unique yet thoroughly social and political. The need to reiterate this challenge to overcome dualities, often framed as ambivalence or paradox, is not only telling of the researchers' task, but of the global discussion on Africa, youth and politics in the 2010s, of which researchers are inherently part. A tendency to underline agency despite hardship or victimizing circumstance is typical for the research on exclusion or oppression everywhere (Jungar and Oinas 2011), but perhaps especially urgent in Africa with its on-going neo-colonialisms, not least in the sphere of academic knowledge practices (Kontinen and Oinas 2015). The task then, regardless of location, is to untie the connection between victimizing social reality and an assumption of an automatic, stigmatized identity category. Scholars publishing on Africa thus require an extra sensitivity in terms of how to address different publics. We can be both responsible allies and constructive critics when witnessing the practices of young people.

\section{What Engagements? From Uprisings to Vague Discontents}

Writing the anthology in 2016, we are especially attuned to examining what the initial promise of popular uprisings in North Africa have meant for young people in the entire region, but also outside their specific geographical areas, as a source of inspiration and frustration. Moving further south, what have the 20 years of post-apartheid transition, its hope and the potential of democracy as an idea, in and beyond South Africa, meant for today's young people who seem to be getting increasingly pessimistic and angry?

While attending to the diversity of experiences, the authors, in their own ways, examine the contours of what political engagement could mean. As reflected in the book's title, What politics? the concept of political engagement is operationalized here to refer to different kinds of activities, or ways of being 
and doing, through which young people engage in their immediate and imagined social environments with an aim of making best of them. At the same time, the book offers insights into the striking similarities in thinking and struggles among young people in Africa today. We especially take the quests for livelihood and belonging, social worth and dignity into the equation of what is at stake when coming of age. The comparative and contrastive reading of several cases reveals different ways in which 'politics' could be conceived in the lives of young people themselves. While the chapters discuss various contexts that differ in terms of state formation and democratic structures, postconflict developments, NGO involvement, donor funding and global connections, they collectively evoke new questions to be asked when letting concepts travel.

In particular, we wish to challenge assumptions about the parameters of what constitutes political participation, and highlight a set of features that go against the grain in ways that destabilize the classical tools of the trade when analysing political agency. Our point of departure is the obvious observation that a restricted focus on formal processes of political participation in Africa (or elsewhere) does not suffice (e.g. Mamdani 1996; Lust-Okar and Zerhouni 2008; Jabberi and Laine 2015). Although civil society campaigning, social movements, party politics, elections and public 'high-level' politics do matter, and shape young people's lives, an effort is made here to move simultaneously beyond state-oriented analysis and toward the questions of what matters to the young themselves. For instance, lifestyle choices, generational struggles and access to material resources within and beyond these public arenas are of interest, and bear witness to the more varied social dynamics at play. At the minimum, it has not been for us to decide a priori what are, for young people, the relevant ways of engaging and belonging in the social world. Even seemingly mundane acts and practices that often go unnoticed may serve to extend the experience of being young and, in sufficient numbers, contribute considerably to social change (Bayat 2010; Onodera 2015).

Politics, policy and the political have a tarnished, self-interested and corrupted affective value in many African contexts (Chabal 2009). Young people often distance themselves from the given political identities and affiliations, even in the midst of revolutionary upheaval, so as to imagine the content of politics anew. For those willing, the doors to formal political participation are guarded by gender and especially age-based hierarchical structures. Several chapters discuss gerontocracy and patrimonialism as features that shape the landscape wherein young people must try to manoeuvre. Even when aspiring to autonomous agency young activists are suspected of being mere puppets of somebodyelse'sagenda, narrowing thefield of sincere politicalaction. 
Disillusionment, suspicion and even paranoia are sentiments that loom in attempts to mobilize. The label of being manipulated, bought or brainwashed, whether by donors, Western ideas or local Big Men, haunts attempts to carve out a space for deliberation.

There are clear similarities in how state structures and power elites are viewed with suspicion among youth globally, but it is also important to bear in mind the contextual differences in public engagement. While in some contexts the frequency of public protest can indicate declining trust in public institutions, it may also be so that a paucity of civic engagement and demonstrations signals that faith in the state been lost. For example, in Nigeria public protest is far rarer than in South Africa, where people, especially the marginalized, engage in thousands of small and large scale protests annually (Brown 2015). Perhaps the South Africans have remained more hopeful regarding state delivery of services than the average Nigerian who no longer believes in public services at all? Lack of political engagement may indicate either contented or utterly disappointed citizens. Some choose to disengage out of disinterest, others out of disgust and disillusionment (Ekman and Amnå 2012). The student protests in South Africa possibly indicate the end of an era and the final heart beats of a failing democracy, or perhaps a re-energizing of the political landscape and a renewed commitment to the public arena among youth. Only time will tell.

\section{Individualism and Political Subjects}

For today's youth key issues are resources and social justice, even when they take the shape of acts of consumerism and seemingly vain representations of selfhood. Thus, from working on explicit uprisings, activism, political participation and struggles for rights, the chapters move on to explore music, friendships, feminism and globally circulating tastes, commodities and ideas. Nor should we overlook repetitive everyday survival, gestures of destruction and active withdrawal as political articulations, even if the young do not frame these activities as 'political'.

Attempts to go beyond formal and institutionalized political engagements towards questions of what young people seek in their everyday lives encounter the issue of individual good versus collective good. For example, can we view conspicuous consumerism as an active attempt to challenge racist assumptions of worth and dignity in Southern Africa (Mupotsa 2015) and beyond? The individualizing ethos of contemporary capitalism seeps into discourses everywhere, and while often described as a 'Western' preoccupation, it is a global phenomenon whose articulations can be detected in the chapters here. Is 
individualism in conflict with a wider sense of collective resistance, or perhaps another dimension of any social engagement today? The case studies in this book confirm that individualism versus a more collective mode of existence is a false problematic. More generally, the widespread and negatively coded assumptions of today's youth as materialistic and individualistic are investigated in this volume, as we argue that such aspirations can be seen as a desire for lived practices of dignity, equality and justice.

Childhood researchers Jouni Häkli and Kirsi Pauliina Kallio (2013) discuss the difficulty scholars often face when exploring children's and young people's political agency and resistance, and their need to overcome the analytical dichotomy between two extremes, whereby

at one end stands the subject as self-sufficient, enduring and sovereign individual, from which all consciousness and action springs. At the other end the subject dissolves into a non-sovereign product of social and discursive construction, devoid of any stability, autonomy and unity of self.

HÄKLI and KALLIO 2013, 4

In African Studies, individualizing theory traditions are contrasted with the assumption of more collectivist cultures in Africa (e.g., Tamale 2011). The emphasis on the collective embeddedness of the self is welcome, but should not exceptionalize African subjectivities; rather, the need to examine the relationality and dynamism between the possibly imagined self and collective life should be insisted upon everywhere.

In this book, we seek passages and insights into the realm between the intersubjectively constituted self(hood) and the social context which the individual reflects upon and is embedded in. Political structures, like the state or the market, are exemplary institutions where subjectivities are constituted, possibly in meaningful and empowering ways, but the immediate experiences of young people often evolve in more mundane settings that are generally more important for them, such as schooling, family, friendship circles and the workplace. The chapters provide empirical interrogations of the concept of the subject and the social, meanwhile generating meaningful tools for analysing the subjectification processes that are specific to contexts of assumed lack of social security, gender equality and avenues for formal participation in politics.

Creative technologies of the self may take unexpected forms, and lead to interruptions that can seem incomprehensible to researchers (Oinas 2015). We may find "subjects who cannot speak, refuse to speak; subjects who unravel, who refuse to cohere; subjects who refuse 'being' where being has already been defined in terms of a self-activating, self-knowing, liberal subject" (Halberstam 
2012, 186). However, we can learn to see such acts of disruption and destruction as political, and in many ways meaningful. The affective dimensions of the political present an area of research that is fruitful for the study of youth and politics in contemporary Africa. It comes with the opportunity to trace and understand prevailing sentiments, such as the "anger of exclusion, of unquestioned privilege, of racial distortions, of silence, ill-use, stereotyping, defensiveness, misnaming, betrayal, and co-optation" (Lorde 1981) among young people. These can, although not without difficulty, translate into academic accounts of political engagements.

Recently, research on queer Africa has reconfigured ways to express the personal as political in a number of volumes mixing academic and creative writing, as well as the political and personal voice (e.g., Gunkel 2010; Tamale 2011; Ekine and Abbas 2013; Matebeni 2016). In queer research, mere staying alive and the work to be regarded human is political. Zethu Matebeni argues in the recent book, Walking the Tightrope, that often "LGBT people are regarded as less than human - opposing the nature of things and godly creations", adding: "Those of us who do not have the pleasure of taking life for granted are constantly reminded of the struggle to be human. It is not merely a matter of being given an intrinsic right because even that can sometimes leave you insufficient" (Matebeni 2016, no number). In this volume we aim to follow her lead into the issues of "connectedness; fragility; fluidity; malleability; plasticity; failure; achievement and resistance" (ibid.).

Lastly, it is important to end this discussion of what constitutes the "political' for young people in Africa today with a reminder that while researchers tend to study admirable examples of engagement, many youthful engagements are also destructive, conservative and oppressive. In any society some young people strive to pass and belong, using the tools of the existing hierarchies of power. There are those whose actions strengthen current positions of power and others who merely aspire to maintain the status quo but access its resources. On the more progressive spectrum of change there are those whose involvement is mainly a rejection of the contemporary situation, while others seek to expand the existing horizons. Who is to evaluate the worth and morality of any such agency? As in the legacy of youth research, rather than political science and development studies, we are hesitant to judge, and aspire rather to achieve better understanding without excessive romanticizing.

\section{Contents}

This book examines the experiences of being young in today's Africa, using qualitative methodologies in a variety of social science disciplines, especially 
in the fertile intersection between development studies and youth research, fields that seldom interact. The contributors represent both established and upcoming scholars in their respective fields. We consider the richness of empirical cases and multiple standpoints a positive quality of the present volume. For example, through the application of comparison we can ask why in a South African university some girls were able to challenge and politicize sexual violence through formal channels (Mitchell, de Lange and Moletsane, this volume), when hypocrisies of sexual cultures can be problematized only through silent graffiti in Addis Ababa University (Mulumebet, this volume). Policies and staff play a role, too. Contrasting contexts can bring to fore characteristics that might otherwise be so taken for granted that we do not notice them. We hope to produce suggestions for shared theoretical questions that can travel.

One aim of this book is to explore young people's engagements by critically examining, yet not completely withdrawing from, the clearly defined language of politics and ideology. It offers multiple viewpoints onto the experiences of young people as to their (assumed) roles, place, positions and experiences both within and beyond formal political structures and institutions or so-called public political spaces. In doing so, it also challenges the dichotomy of voluntary and involuntary agency. It is important to contest the idea that everyone has the freedom to choose their own singular path, even while valorizing the energy and drive to seek out new ways of belonging and breaking free. Political structures in Africa are often described as gerontocratic and clientelistic, thereby hampering young people's political participation and life transitions. This tendency is supported by the findings here, although these institutions also offer spaces through which normative notions of political participation, and the young people's experiences thereof, can take new shapes.

The collection is organized into three sections on the basis of the orientations of engagement among the young people, thus moving beyond analytical dichotomies, both alarmist and celebratory, and providing instead empirically grounded analyses that reveal what is shared and what is unique in different contexts and locations across the continent. The sections, called 'Envisioning', 'Entitlement' and 'Embeddedness', are not presented as ways to promote rigid analytical divisions but to draw attention to the multiple dimensions of everyday experience in which young people engage and of which they are part.

\section{Envisioning}

The first section emphasizes creative agency and youthful aspirations for personal and collective autonomy. Here new ideas and ideals of engagement are highlighted among, by and for young people themselves, outside formal political arenas. Alternative expressions of citizenship, decency and respect are central to the activities described in this section. Yet, even though they are youth-led, 
youth-oriented and in the here and now, they may have a legacy of prior movements, such as the youth movement against apartheid (Mupotsa, this volume), for example, or past generations of student activism (Adamu and Balsvik, this volume). Similarly, an orientation towards youth does not limit the scale of action: the wish to generate a contemporary movement dealing with issues important to the young today, like the high cost of education, does not exclude an aspiration to address larger political issues of urgency like the state of democracy (Mupotsa, this volume) or morality (Sounaye, Alava, this volume). These cases challenge the assumption that young people's grievances can be sidelined or suspended as less central to current, actual, serious political questions. These youth are not future political agents, but contemporary.

Autonomous action and a desire to work with and for other young people, have been typical features historically, often with successful outcomes, whether expressed in the form of student unions, political party youth leagues or youth wings of revolutionary (underground) movements, all of which have played important roles in African history (Resnick 2015). Currently, however, in the face of prevailing gerontocracy, the youth-orientedness of their initiatives may lead to the marginalization of their views. The chapters discuss the contexts of student politics and youth-led NGOs as well as the more informal sides of youth activism, revealing the multiple pitfalls the actors are compelled to negotiate when engaging with formal and informal avenues to public life. The authors in this section also discuss generational dynamics and gerontocratic power structures and relations that may block participation, at the same time reiterating that current scholarship cannot and should not predict where youth networks might lead and what forms they may acquire in the longue durée.

Danai Mupotsa offers a reflection on the recent student activism, the \#FeesMustFall, at the University of the Witwatersrand in South Africa. Mupotsa suggests that the movements use the biographical 'moments' of awakening to expose the failed promise of democracy - which is caught up in dialectical struggles about the university, its promises and institutional life - with their awareness of the impossibility of recognition. Mupotsa's argument underlines the importance of not getting trapped in either-or polarizing analysis; a personal interest in access to education through lower fees, and political engagement in the struggle for a more democratic society are different sides of the same coin. Student protest is simultaneously self-interested, pragmatic and utopian.

Henri Onodera explores the everyday lives of young activists before the 2011 uprisings in Egypt, discussing the ambivalent roles of friendship in the context of their democratic struggle. On the one hand, relations of friendship provided 
invaluable support in times of crisis and struggle, yet, being so precious, they were also fragile, constantly shifting and subject to manipulation. Despite sharing their dissent against the incumbent authorities, keeping and negotiating one's friendship, including the trust and loyalty that were involved, proved to be one of the most meaningful of everyday engagements for activist youth, hinting at the ways that micro-level relationships could provoke broader visions of how society and politics should be organized.

For many young people formal institutions are not to be trusted, and traditional political ideologies are less compelling compared to, for example, cultural, religious, ethnic or consumerist engagements. Although these engagements take a step away from the formal political realm, even abandoning the very word 'political', the chapters argue for the importance of making sense of political messages and rhetoric embedded in these forms of engagement. Sofia Laine, Leena Suurpää and Afifa Ltifi explore the roles and meanings of music in the collective engagement of young musicians in Tunisia, deploying the concept of 'respectful resistance' to discuss how young musicians in Tunisia strive for social change while not insisting on overt confrontation with society and its prevailing social order. Mounir Saidani also discusses Tunisian youth, arguing that due to their disappointments after the revolution, young activists have turned to the arts as a channel for their engagements. In their chapter, Ehaab Abdou and Loubna H. Skalli inquire whether youth-led organizations in Egypt's NGO sector form alternative spaces for political participation, and the role that their claim to being 'non-political' plays in this context.

Mulumebet Zenebe explores graffiti on the campus of the of Addis Ababa University (AAU) in Ethiopia as silent resistance and a way of addressing, for example, questions of ethnic and sexual boundaries. Importantly, she also underlines that youthful agency is not only progressive and should not be celebrated and romanticized for its mere existence, but analysed critically. For example, graffiti as a phenomenon does important work in expanding the space for expression under a repressive regime and cultural climate, but, as to their content, more often than not the AAU graffiti rather cements than contests old hierarchies, by slandering female sexual desire, for example. While a lot of the analysis in this first section points to a drive to break free and imagine and generate new landscapes for participation, youth are seldom so distanced that they do not also utilize existing dynamics and resources of power.

\section{Entitlements}

The second section highlights young people's efforts to claim and justify their right to resources that elsewhere or for other people seem taken for granted. Aspirations to belong and be entitled to a role in society also involve quests for 
material justice and life chances in the future. The authors here demonstrate that struggles for dignity, change and livelihood, including desires for materially defined success in life, co-exist in young people's everyday lives and dreams. The realms of the ideological and the material should not be juxtaposed when analysing young people's agency in precarious circumstances (Butler and Athanasiou 2013).

The material struggles of young people in contemporary Africa are often relegated to the informal economy. Access to a position in the formal economy is less likely to be within reach, and may come with unacceptable terms, for example, at the cost of autonomy. Lack of access to loans, funds and networks to start a small enterprise is a widely shared obstacle for young people on the continent (Aït Mous 2016). This is enhanced by a reasonable lack of trust in management practices and the hierarchical and authoritarian leadership styles in the often neo-patrimonial formal sector. Some even ask if formal education today is relevant in terms of providing adequate skills for the contemporary labour market, especially for the creative 'hustling' that seems to be one avenue of manoeuvre for youth. Hustling for personal or group-based gain means making do, coping, even being successful on a short term basis, but without the glamour of the 'start-up' of their Northern counterparts. Yet making it for the moment can in many circumstances be a political act in itself, simply because it is an activity that also makes a claim on the future - constituting a demand to be seen as someone to be reckoned with, as occupying a space - or, sometimes, that simply shifts the terms of what making it, success or looking cool means (Ratele 2016).

Jesper Bjarnesen's chapter deals with diaspora youth in urban Burkina Faso who end up being engaged in political campaigns. Their involvement reflects their 'diaspo' position in society, admired and rejected at the same time. The politics of inclusion and exclusion can be successfully exploited by the Big Men politicians with cash, but also by the young men themselves. Nanna Jordt Jørgensen's chapter discusses young people's claims to meaningful roles in the local sand business in Northern Kenya, and how they hustle not only for their rights to broker the scarce natural resource but also for their visions of how the community should be organized.

Henni Alava's Northern Ugandan Christian informants describe their views of themselves and their future hopes as explicitly non-political, paradoxically allowing Alava to delineate the political dimension in this claim. The withdrawal from anything political to Christianity and decency must be understood against the post-war setting. These youth are clearly not radical in their views; rather, they choose to turn to a conservative institution, a mainline church - but in a setting where attaining a peaceful, respectable life is an 
achievement, and holding on to the right to a good life marks a political stand. Mariko Sato's study on return migrant women in Somaliland explores the context of return migration, connecting to the chapters of Bjarnesen and Armila et al. on migrant youth. The optimism and willingness to generate change can be channelled through a commercial business, but aspiration and hope can be read as a political move of commitment - that in Sato's study was not always welcomed by the locals, however. To be perceived as a viable threat to existing power dynamics is, of course, evidence that these women have political potential. Tilo Grätz examines the agencies of young radio and media professionals, showing how they build and maintain relations with their audiences as a way to securing and opening life chances in the Republic of Benin.

The entire section challenges the distinction between deep and shallow commitments. The authors examine how following an opportunity or flow of events may change the path of one's life, or put it in danger. Yet the discussions also indicate that regarding these engagements as void of ethical reflection or aspiration to contribute to the wider community is a hasty conclusion. For example, the simple act of demanding an embodied right to be present and to be hailed as a citizen with dignity (Brown 2015) can be radical in the case of migration. This can apply within a city, too, due to socio-economic distances, as expressed by the student protestors in South Africa who claim that black students in elite universities, even when natives of the same city, can when on campus live with “a permanent sense of exile. You don't belong” (Mupotsa, this volume, 24).

\section{Embeddedness}

The third section addresses the multiple ways in which youth engage in existing, formal structures of power, exploring how the normative notions of political participation are experienced in contemporary Africa, as numbers of young people do engage with, and seek access to, political institutions and public political space. In his chapter, Abdoulaye Sounaye examines the emergence of the Salafi youth movement in Niamey, Niger, and the ways in which piety activists on university campuses consider their role in the promotion of religious revivalism in the society as a whole. Through religious commitment a new entitlement to political advocacy has opened itself for these young people. Eija Ranta has interviewed young Kenyans active in the 2013 elections, who now wonder how limited the role of their agency was and will be in the future. Ranta's youth are disillusioned but not entirely pessimistic, and they do envision room for change beyond ethnicized party politics.

In his chapter, Ivo Mhike discusses the views and reflections of young Zimbabweans on their experiences in the state-sponsored National Youth 
Service Programme in the early 20oos. The programme was portrayed as an opportunity for youth to participate in national empowerment, but the testimonies of Mikhe's informants' bear witness to acts of violence, and circumstances that make participation far from voluntary. In contrast, Päivi Armila, Marko Kananen and Tiina Sotkasiira discuss Somali diaspora youth in the United States and Finland, who actively seek opportunities to participate in their countries of location. Abebaw Yirga Adamu and Randi Rønning Balsvik study student politics in Ethiopia in a historical perspective.

Póra Björnsdóttir and Jonina Einarsdóttir explore the ways in which development policy approaches children's rights, and participation turns into development practice, and the children's views thereof, in today's Ghana. As in the chapters by Jorgensen and Laine, Suurpää and Ltifi, Björnsdóttir and Einarsdóttir argue that there is a dimension to age-based hierarchies that needs further examination. Often the respect for tradition and elders is seen as a culturally valuable trait that ideas about individual freedoms challenge. Resistance to overthrowing cultural values and traditions, like respect for elders, gives rise to acutely important discussions across the continent, from Boko Haram to violence against LGBTI youth (Ratele 2016). These concerns were expressed by young and old alike in Björnsdóttir and Einarsdóttir study, which also suggests that such juxtaposition has been overcome and children's rights can be upheld without disputing the importance of respect to Ghanaian core values. Nationalistic resistance to allegedly 'Western' influences are discussed throughout the book as sites of important negotiation and politicized battles over the history of the present, where decolonization is but one means to shape those values.

Lastly, Claudia Mitchell, Naydene de Lange and Relebohile Moletsane show how university students were able to challenge sexual violence in South Africa in practical and locally relevant ways. Here, formal methods of influencing policy were used but, by prioritizing the young women's own views and voices, in ways that they felt empowering. What remains to be further explored, by both researchers and organizations, is how to act as a good ally and supportive collaborator to these kinds of semi-autonomous youth groups navigating formal power.

Some of the chapters here show that difficulties are felt by young people when attempting to engage in meaningful political activity in the formal sphere. A political climate where suspicion of manipulative politics overshadows youthful activity tarnishes its participants. In the general political atmosphere of disillusionment and corruption, it is important to remember that the circumstances for agency are not of the young generation's own making. Agency and lack of it needs to be historicized. 
One of the lessons of the chapters is that agency can be studied as both uniquely individual and shaped by its circumstances, a paradox that is actually not a paradox at all (Jungar and Oinas 2011). A sense of achievement and hope may come from a conservative religious group as in the case of Niger (Sounaye, this volume), or a project that addresses important issues for the youth themselves yet is labelled 'Western' as in cases of feminism (Mitchell, de Lange and Moletsane, this volume) or child rights (Björnsdóttir and Einarsdóttir, this volume). What these share, however, is the scepticism directed at them that suggests that the movements are orchestrated and manipulated by foreign sources of power, rendering the young mere pawns. The joy of unique ownership of the engagement felt by those young people involved can, however, be genuine and should not be mistrusted, as ideas have always travelled and generated new ones. Such agency and sense of ownership becomes analytically interesting and intelligible when studied against the options and the material and discursive parameters available in the time and place. While the book emphasizes youthful agency its key message is that any engagement takes place in a context, and social scientists are capable of examining the expressed experiences and how they are historically shaped; the analytical lens does not require dismissal of the affective and the personal. We hope that the book has succeeded in being faithful to the informants while expanding analysis in time and space, and connecting the cases presented here to other research. Although this volume focuses on Africa, it is a collective effort to reach a better understanding of what is it like to be young today, and what the making of tomorrow's yesterday means to them.

\section{References}

Abbink, Jon, and Ineke van Kessel, eds. 2005. Vanguard or Vandals: Youth, Politics, and Conflict in Africa. Leiden: Brill.

Aït Mous, Fadma, 2016. "Youth (un)employment in Morocco: discourses, policies and youth strategies." Keynote lecture held at the Youth Research Days 2016 at the University of Helsinki, 8 November 2016. Youtube video, 41:07. Video uploaded by Nuorisotutkimusseura \& Nuorisotutkimusverkosto [Finnish Youth Research Network] 14 November 2016. https://www.youtube.com/watch?v=h_CPcIrDqTU (accessed 31.01.2017).

Allaste, Airi-Alina, and David Cairns. 2016. "Introduction: Youth Political Participation in a Transition Society." Studies of Transition States and Societies 8 (2): 3-10.

Bayat, Asef. 2010. Life as politics: How ordinary people change the Middle East. Stanford: Stanford University Press. 
Brown, Julian. 2015. South Africa's Insurgent Citizens. On Dissent and the Possibility of Politics. London: Zed Books.

Butler, Judith, and Athena Athanasiou. 2013. Dispossession: The Performative in the Political. London: Polity Press.

Chabal, Patrick. 2009. Africa: The Politics of Suffering and Smiling. London: Zed.

Christiansen, Catrine, Mats Utas, and Henrik E. Vigh. 2006. "Introduction." In Navigating Youth Generating Adulthood: Social Becoming in an African Context, edited by Catrine Christiansen, Mats Utas, and Henrik E. Vigh, 9-28. Uppsala: Nordiska Afrikainstitutet.

Clark-Kazak, Christina Rose. 20o9. "Towards a working definition and application of social age in international development studies." Journal of Development Studies 45 (8): 1307-1324.

della Porta, Donatella, and Mattoni Alice. 2014. Spreading Protest: Social Movements in the Times of Crisis. Colchester: ECPR Press.

Ekine, Sokari, and Hakima Abbas. 2013. Queer African Reader. Oxford: Fahamu Books/ Pambazuka Press.

Ekman, Joakim, and Erik Amnå. 2012. "Political participation and civic engagement: Towards a new typology." Human Affairs 22 (3): 283-300.

Feixa, Carles, Carmen Leccardi, and Pam Nilan, eds. 2016. Youth, Space and Time. Agoras and Chronotopes in the Global City. Leiden: Brill.

Gqola, Pumla Dineo. 2015. Rape. The South African Nightmare. Auckland Park: Jacana.

Gunkel, Henriette. 2010. The Cultural Politics of Female Sexuality in South Africa. London: Routledge.

Halberstam, Jack. 2012. “Going Gaga: Dissent, Refusal and Feminism.” In Undutiful Daughters, edited by Henriette Gunkel, Nigianni Chrysanthi, and Fanny Söderbäck, 184-194. New York: Palgrave Macmillan.

Honwana, Alcinda. 2012. The Time of Youth: Work, Social Change, and Politics in Africa. Kumarian Press.

Honwana, Alcinda. 2014. "Waithood': Youth transitions and social change." In Development and equity, edited by Dick Foeken, Ton Dietz, Leo Haan, and Linda Johnson, 28-40. Leiden: Brill.

Honwana, Alcinda, and Filip de Boeck, eds. 2005. Makers \& Breakers: Children \& Youth in Postcolonial Africa. Oxford: James Currey.

Häkli, Jyrki, and Kirsi P. Kallio. 2013. "Subject, Action and Polis: Theorizing Political Agency." Progress in Human Geography 38 (2): 181-200.

Jabberi, Fatma, and Sofia Laine. 2015. "Spaces of Dialogue? The Case of the World Social Forum Tunis 2013 from the Perspective of Young, Local Volunteers." Global Studies of Childhood 5 (2): 178-190.

Jungar, Katarina, and Elina Oinas. 2011. "Beyond Agency and Victimization: Re-reading HIV and AIDS in African Contexts." Social Dynamics 16 (3): 248-262. 
Kelly, Peter, and Annelies Kamp, eds. 2015. A Critical Youth Studies for the 21st Century. Leiden: Brill.

Kontinen, Tiina, and Elina Oinas. 2015. "Knowledge Practice in Development Studies: Examples from Ethnographies on Civil Society." In Contemporary Concerns in Development Studies: Perspectives from Tanzania and Zambia, edited by Rehema Kilonzo and Tiina Kontinen, 178-193. Helsinki: Publications from the Department of Political and Economic Studies 23.

Laine, Sofia, Elina Oinas, Leena Suurpää, Tiina-Maria Levamo, Henri Onodera, Piia Lavila, and Minna Rantama. 2015. "Polyphonic Ethos in Team Research: Lessons from the World Social Forum, Tunis 2013." In "In Search of ..." New Methodological Approaches to Youth Research, edited by Airi-Alina Allaste and Katrin Tiidenberg, 116-135. Cambridge: Cambridge Scholars.

Lorde, Audre. 1981. "The Uses of Anger: Women responding to Racism." Keynote presentation at the National Women's Studies Association Conference, Storrs, Connecticut.http://www.blackpast.org/1981-audre-lorde-uses-anger-women-responding -racism (accessed 5 February 2016).

Lust-Okar, Ellen, and Saloua Zerhouni, eds. 2008. Political Participation in the Middle East. London: Lynne Rienner.

Mamdani, Mahmood. 1996. Citizen and Subject: Contemporary Africa and the Legacy of Late Colonialism. Princeton Studies in Culture/Power/History. Princeton, NJ: Princeton University Press.

Matebeni Zethu. 2016. "Introduction. Walking the Tightrope." In Walking the Tightrope. Poetry and prose by LGBTQ writers from Africa, edited by Abayomi Animashaum and Irwin Inakukunda, no page numbers. Maple Shade: Lethe Press.

McEvoy-Levy, Siobhán, ed. 2006. Troublemakers or Peacemakers? Youth and Post-Accord Peace Building. University of Notre Dame Press.

Muhula, Raymond. 2007. "Youth and Politics in Kenya: Promise or Peril?" Africa Insight 37 (3): $362-375$.

Mupotsa, Danai S. 2015. "Becoming Girl-Woman-Pride." Visual Interruptions, a special issue of Girlhood Studies 8 (3): 73-87. doi: http://dx.doi.org/10.3167/ ghs.2015.080307.

Oinas, Elina. 2015. “The Naked, Vulnerable, Crazy Girl." Visual Interruptions, a special issue of Girlhood Studies 8 (3):119-136. doi: http://dx.doi.org/10.3167/ghs.2015.080310.

Onodera, Henri. 2015. "Being a young activist in the late Mubarak era: An ethnography of political engagement in Egypt." PhD diss., University of Helsinki, Helsinki. Helsinki: Department of Political and Economic Studies.

Perullo, Alex. 2005. "Hooligans and Heroes: Youth Identity and Hip Hop in Dar es Salaam, Tanzania." Africa Today 51 (4): 75-101. doi:10.1353/at.2005.0045.

Philipps, Joschka. 2014. "Dealing with diversity: African youth research and the potential of comparative approaches." Journal of Youth Studies 17 (10): 1362-1377. 
Posel, Deborah. 2005. Sex, Death and the Fate of the Nation: Reflections on the Politicization of Sexuality in Post-Apartheid South Africa. Africa: Journal of the International African Institute 75 (2): 125-153.

Ratele, Kopano. 2016. Liberating Masculinities. Cape Town: HSRC Press.

Resnick, Danielle. 2015. "Protesting for better tomorrow? Youth mobilization in Africa." In African Youth and the Persistence of Marginalization, edited by Danielle Resnick and James Thurlow, 67-84. New York: Routledge.

Rescnik, Danielle, and James Thurlow, eds. 2015. African Youth and the Persistence of Marginalization. New York: Routledge.

Seekings, Jeremy. 1993. Heroes or Villains? Youth Politics in the 1980s. Johannesburg: Ravan Press.

Singerman, Diane. 2007. "The economic imperatives of marriage: Emerging practices and identities among youth in Egypt." Middle East Youth Initiative Paper 6/2007. Wolfensohn Center for Development \& Dubai School of Government.

Suurpää, Leena, Johanna Sumiala, Titus Hjelm, and M. Tikka. 2015. "Studying youth in the streets of the media city: Field notes on a relational perspective." In Observatorio (OBS), Special Issue 'Media City - Spectacular, Ordinary and Contested Spaces', 177-191. doi: http://dx.doi.org/10.7458/obsoo2015977.

Tamale, Silvia. 2011. African Sexualities: A Reader. Oxford: Fahamu/Pambazuka Press.

United Nations, Department of Economic and Social Affairs, Population Division. 2015. World Population Prospects: The 2015 Revision, Key Findings and Advance Tables. Working Paper No. ESA/P/WP.241. 